Article

\title{
Numerical Investigation of Solid-Fueled Chemical Looping Combustion Process Utilizing Char for Carbon Capture
}

\author{
Xiaojia Wang ${ }^{1, *}$, Xianli Liu ${ }^{1,2}$, Yong Zhang ${ }^{1}$, Bo Zhang ${ }^{1}$ and Baosheng Jin ${ }^{1}$ \\ 1 Key Laboratory of Energy Thermal Conversion and Control of Ministry of Education, School of Energy and \\ Environment, Southeast University, Nanjing 210096, China \\ 2 China Energy Engineering Group Jiangsu Power Design Institute Co. Ltd., Nanjing 211102, China \\ * Correspondence: xiaojiawang@seu.edu.cn
}

Received: 20 July 2019; Accepted: 3 September 2019; Published: 6 September 2019

check for updates

\begin{abstract}
The in-depth understanding of the gas-solid flow and reaction behaviors, and their coupling characteristics during the chemical looping combustion (CLC) process has the guiding significance for the operation and optimization of a chemical looping combustor. A three-dimensional numerical model is applied to investigate the char-fueled CLC characteristics in a fuel reactor for efficient $\mathrm{CO}_{2}$ separation and capture. Simulations are carried out in a bubbling fluidized bed fuel reactor with a height of $2.0 \mathrm{~m}$ and a diameter of $0.22 \mathrm{~m}$. The initial bed height is $1.1 \mathrm{~m}$, and hence the height-diameter ratio of the slumped bed is five. The oxygen carrier is prepared with $14 \mathrm{wt} \%$ of $\mathrm{CuO}$ on $86 \mathrm{wt} \%$ of inert $\mathrm{Al}_{2} \mathrm{O}_{3}$. In the process of mathematical modeling, a Eulerian-Eulerian two-fluid model is adopted for both of the gas and solid phases. Gas turbulence is modeled on the basis of a $k-\varepsilon$ turbulent model. The reaction kinetics parameters are addressed based upon previous experimental investigations from literature. During the simulation, the gas-solid flow patterns, composition distributions, and reaction characteristics are obtained. Moreover, the effects of solids inventory and fluidizing number on the reaction performance are elucidated in-depth. The results have shown that the reaction rates have close relationship with the flow patterns and the distributions of gas concentrations. Compared to the steam-char gasification over sand, the application of char-fueled CLC can effectively promote the conversion of gasification products. In addition, higher $\mathrm{CO}_{2}$ concentration at the outlet can be achieved by increasing the initial solids inventory or decreasing the fluidizing number. Some calculated values are verified by the previous data, indicating that the current three-dimensional models are reasonable to study the process mechanism of char-fueled CLC.
\end{abstract}

Keywords: chemical looping combustion; char; numerical simulation; fuel reactor; bubbling fluidized bed

\section{Introduction}

With the deterioration of global warming, the emission of greenhouse gas $\mathrm{CO}_{2}$ has drawn increasing attention. Many technologies, such as amine scrubbing in post-combustion, chemical looping combustion (CLC), and oxy-fuel combustion, have been proposed to be applied in the electric power industry so as to reduce the greenhouse effect by $\mathrm{CO}_{2}$ [1-5]. Among them, CLC technology, by virtue of its intrinsic attribute of isolating $\mathrm{CO}_{2}$ during the combustion process, is regarded as the most promising option in $\mathrm{CO}_{2}$ separation and capture with a low energy cost $[3,6]$.

The basis for the concept of CLC is the transfer of oxygen from air to fuel by the circulation of a solid oxygen carrier, which is commonly a kind of metallic oxide. Figure 1 is a conventional scheme with $\mathrm{CuO} / \mathrm{Cu}$ for CLC. This system mainly includes two reactors, known as the fuel reactor and air reactor. The fuel reactor is a bubbling fluidized bed (BFB) in which the oxygen carrier is reduced 
by the fuel. When the fuel is fully converted, there are only steam and $\mathrm{CO}_{2}$ in the flue gases of fuel reactor. Thus, after condensation, a $\mathrm{CO}_{2}$ stream with high purity can be obtained. Then, the reduced oxygen carrier is circulated into the air reactor (usually with a high velocity fluidized bed structure) for re-oxidization by reacting with the air $[7,8]$.

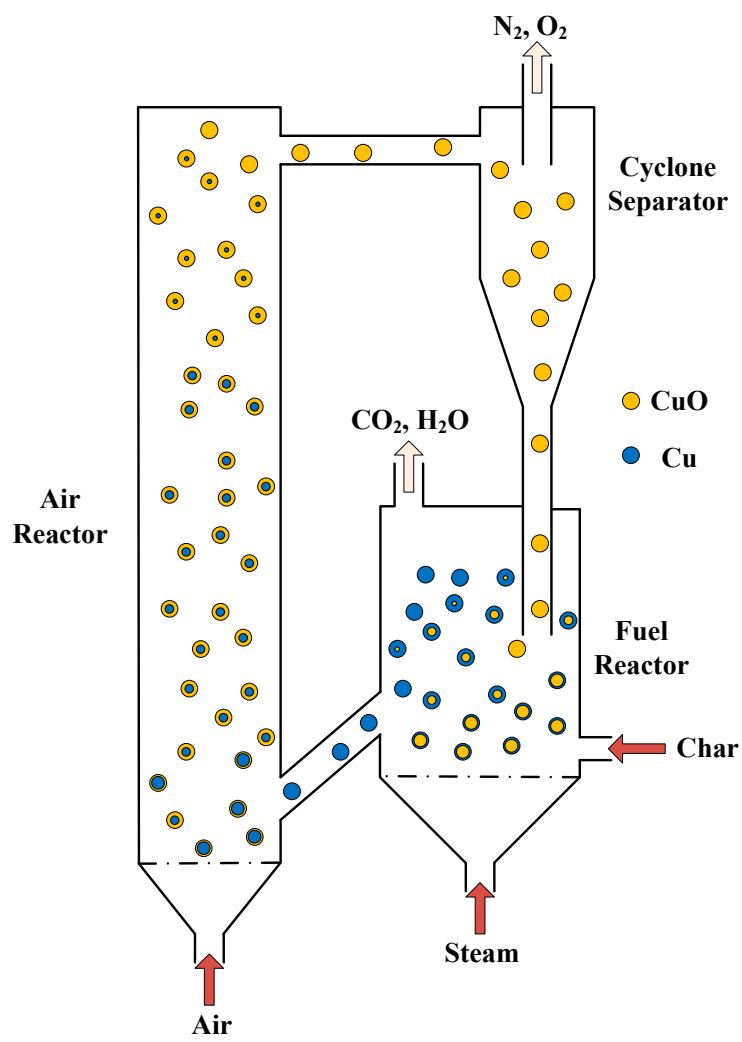

Figure 1. Schematic diagram of a conventional solid-fueled CLC system.

Since the concept of CLC was firstly proposed, the CLC processes with gaseous fuels have been deeply investigated [9-15]. However, due to the more abundant reserves of solid fuels (e.g., coal, char, and biomass) in comparison to gaseous fuels, the adaptation of gas-fueled CLC technology to the solid-fuel combustion is very attractive and necessary [16-19]. At present, the application of solid-fuel CLC is mainly carried out by an approach entitled in-situ gasification chemical looping combustion (iG-CLC). In contrast to gas-fueled CLC, the special feature of iG-CLC is that it integrates the gasification reactions of solid fuels and the subsequent chemical-looping reactions between the gasification products and the oxygen carrier in the fuel reactor [19-22]. Specifically, in the fuel reactor, the fuel (represented by char) is first gasified by $\mathrm{H}_{2} \mathrm{O}$ and $\mathrm{CO}_{2}$ as the following reactions:

$$
\begin{gathered}
C(s)+H_{2} \mathrm{O}(g) \rightarrow \mathrm{CO}(g)+\mathrm{H}_{2}(g)\left(\Delta \mathrm{H}_{1073 \mathrm{~K}}^{\theta}=134.9 \mathrm{~kJ} / \mathrm{mol}\right) \\
\mathrm{C}(\mathrm{s})+\mathrm{CO}_{2}(g) \rightarrow 2 \mathrm{CO}(g)\left(\Delta \mathrm{H}_{1073 \mathrm{~K}}^{\theta}=169.0 \mathrm{~kJ} / \mathrm{mol}\right)
\end{gathered}
$$

The water-gas shift reaction (WGSR) also plays an important role when steam is the main gasification agent [23]:

$$
\mathrm{CO}(g)+\mathrm{H}_{2} \mathrm{O}(g) \rightarrow \mathrm{CO}_{2}(g)+\mathrm{H}_{2}(g)\left(\Delta \mathrm{H}_{1073 \mathrm{~K}}^{\theta}=-34.0 \mathrm{~kJ} / \mathrm{mol}\right)
$$

The oxygen carrier (represented by $\mathrm{CuO}$ ) is then reduced by the intermediate gasification productions to generate $\mathrm{H}_{2} \mathrm{O}$ and $\mathrm{CO}_{2}$ :

$$
\mathrm{CuO}(\mathrm{s})+\mathrm{H}_{2}(g) \rightarrow \mathrm{Cu}(\mathrm{s})+\mathrm{H}_{2} \mathrm{O}(\mathrm{g})\left(\Delta \mathrm{H}_{1073 \mathrm{~K}}^{\theta}=-98.9 \mathrm{~kJ} / \mathrm{mol}\right)
$$




$$
\mathrm{CuO}(\mathrm{s})+\mathrm{CO}(\mathrm{g}) \rightarrow \mathrm{Cu}(\mathrm{s})+\mathrm{CO}_{2}(\mathrm{~g})\left(\Delta \mathrm{H}_{1073 \mathrm{~K}}^{\theta}=-132.9 \mathrm{~kJ} / \mathrm{mol}\right)
$$

In the air reactor, the reduced oxygen carrier is re-oxidized by reacting with the oxygen from the air:

$$
\mathrm{Cu}(\mathrm{s})+1 / 2 \mathrm{O}_{2}(\mathrm{~g}) \rightarrow \mathrm{CuO}(\mathrm{s})\left(\Delta \mathrm{H}_{1073 \mathrm{~K}}^{\theta}=-149.4 \mathrm{~kJ} / \mathrm{mol}\right)
$$

The iG-CLC option has been demonstrated in various pilot-scale experiments [24-34] and all these tests show that this technique is feasible and promising. However, currently, there still exist some difficulties confining its development, mainly with respect to the unsatisfactory fuel conversion and $\mathrm{CO}_{2}$ concentration in the fuel reactor. These two issues are believed to be mainly related to the following factors: (1) The mismatching between the slow reactions of char gasification and the rapid flameless combustion reactions between the gasification products and the oxygen carrier $[22,35,36]$. (2) The unsatisfactory gas-solid flow and contact efficiency in the fluidized bed fuel reactor, including gas bypassing via bubbles, particle cluster, agglomeration, and so on [22,37]. Under the circumstances, a deep understanding of the flow and reaction characteristics in the fuel reactor is significant to the optimization of iG-CLC performance for higher fuel conversion, $\mathrm{CO}_{2}$ concentration, and $\mathrm{CO}_{2}$ capture efficiency. However, to date, related investigations into the gas-solid flow and reaction characteristics mainly focus on the experimental measurements which have a lot of difficulty in acquiring detailed dynamics mechanism without disturbing the original flow field.

With the fast-developing computational technology and simulation methods, computational fluid dynamics (CFD) simulations have been accepted as an important tool to predict complex gas-solid hydrodynamics and reaction mechanisms without breaking gas-solid dynamics properties. Adamczyk et al. [38] constructed a three-dimensional large-scale boiler model to predict the pulverized coal combustion process. Liu et al. [39] successfully integrated a particle shrinkage model into the Eulerian multiphase CFD frame work to describe the fast fluidized-bed pyrolysis of biomass. Wu et al. [40] established a three-dimensional circulating fluidized bed (CFB) model to study the profiles of hydrodynamics, temperature, and gas emission during the oxy-fuel combustion process with a warm flue gas recycle. Nam et al. [41] performed a CFD simulation to predict the effects of different jet/grid air ratio and pressure conditions on the hydrodynamics characteristics of a pilot-scale pressurized fluidized bed gasifier. By far, the simulation studies with CFD method on CLC mainly focus on the gas-fueled CLC [42-52] and fluid dynamics in CLC systems [53-56], and only a few of them have probed into the field of solid-fuel CLC. Mahalatkar et al. [57] pioneered the prediction of solid-fuel CLC performance in the fuel reactor using a two-dimensional model. However, the continuous charging was not viable for their model. Su et al. [58] performed a two-dimensional simulation of a dual circulation fluidized bed (DCFB) iG-CLC system. They investigated the gas leakage behaviors, flow characteristics and combustion performance in the reaction process with coal as fuel. In comparison to three-dimensional simulations, a two-dimensional simulation will inevitably lead to a certain degree of deviation in terms of the reactor geometry and the influence of the wall boundary, which will further affect the prediction accuracy of gas-solid flow and reaction patterns. Hence, it is necessary to develop three-dimensional numerical models in order to study the CLC performance of solid fuel. Sharma et al. [59] and May et al. [60] built a three-dimensional CFB fuel reactor model to predict the hydrodynamics of a megawatt chemical-looping combustion plant. The calculation results for the pressure distribution along the fuel reactor height agreed well with the experimental values. Nevertheless, some deviations were found with respect to the concentration distributions of gas species, which was believed to be related to the improper reactions of the combustible gases with the oxygen carrier. In our previous studies, we have also carried out a series of simulations on CLC. We first developed a three-dimensional numerical model to simulate the gas-fueled CLC process in the BFB fuel reactor $[61,62]$. Thereafter, we successfully built a fuel reactor model with the high-flux circulating fluidized bed (HFCFB) structure to investigate the fundamental features of iG-CLC, including composition distributions, fuel conversions, reaction rates, in the fuel reactor $[63,64]$. Further, we also developed a cold-state full-loop three-dimensional a model to predict the directional 
separation processes of the fine coal particles and the coarse oxygen carrier particles in an HFCFB iG-CLC system [65]. However, few three-dimensional simulation studies have been carried out on the solid-fuel CLC characteristics in a more typical BFB fuel reactor, which includes the challenge of continuous feeding in the dense phase zone. In addition, as mentioned above, the fundamental reaction mechanism of char gasification which is considered as the rate-controlling step of the whole system, and the matching relation between the char gasification reactions and the subsequent redox reactions of the gasification products with the oxygen carrier are still lacking. Also, it's necessary to conduct in-depth investigations of the coupling mechanism between the flow and reaction behaviors.

Extending from the previous studies, this work builds a three-dimensional CFD model to predict the process of char-fueled iG-CLC in a BFB fuel reactor. The gas-solid flow patterns, composition distributions, heterogeneous reactions, and other important characteristics are predicted. The results of these numerical investigations provide a deep understanding of the hydrodynamics and reaction characteristics in the iG-CLC system, which should be hard to come by under the current experimental conditions, and therefore should be significant for the further development of iG-CLC applications. Compared to the previous simulation studies, the main contributions of this work include: (1) realization of continuous feeding in the dense phase zone of a BFB fuel reactor with a three-dimensional model, (2) investigations of the reaction mechanism of char gasification and its matching relation with the subsequent redox reactions of the gasification products with the oxygen carrier, (3) in-depth understanding of the coupling mechanism between the flow and reaction behaviors in the iG-CLC process, and (4) revelation of the differences of reaction performance between the iG-CLC and gas-fueled CLC under different operation conditions.

\section{Materials and Methods}

The fuel reactor selected in this simulation work is a BFB reactor [66]. As shown in Figure 2, the main geometry of the reactor is $2 \mathrm{~m}$ for the height, $0.22 \mathrm{~m}$ for the diameter. Besides, the initial bed height is $1.1 \mathrm{~m}$ with the height-diameter ratio of 5 .

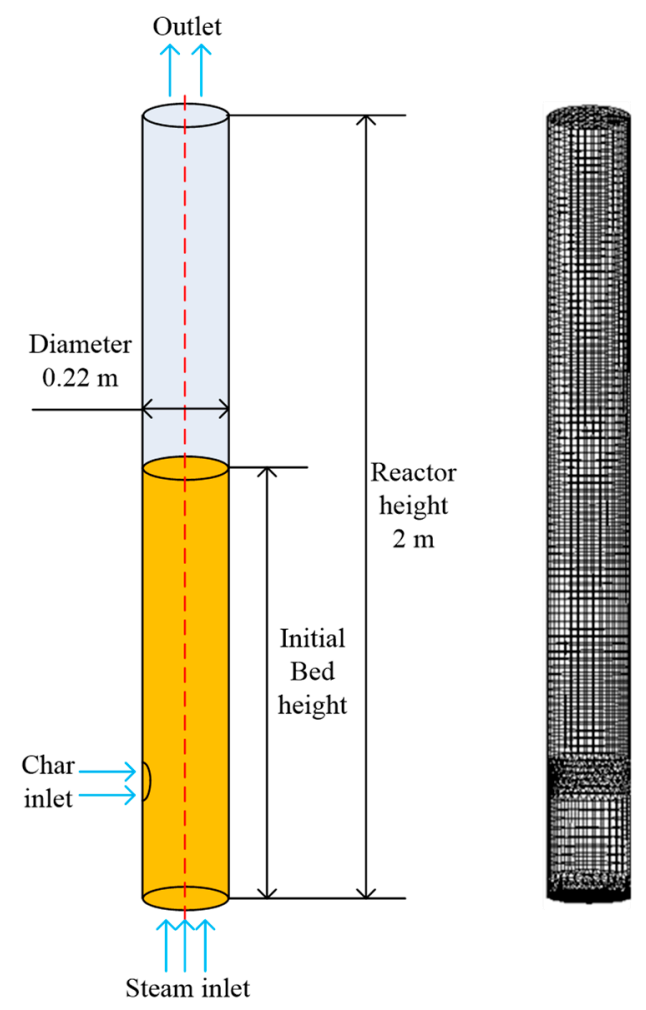

Figure 2. Geometry and mesh model of the BFB fuel reactor. 


\subsection{Hydrodynamic Models}

In this work, in order to get a good convergence, we assume that the particles are spherical and inelastic with uniform size and density, and the difference of temperature in the reactor is neglected. The Eulerian-Eulerian two-phase model is applied to simulate the multiphase flow in the BFB fuel reactor.

The continuity equations for gas and solid phases are given by Equations (7) and (8):

$$
\begin{aligned}
& \frac{\partial}{\partial t}\left(\alpha_{g} \rho_{g}\right)+\nabla \cdot\left(\alpha_{g} \rho_{g} \vec{v}_{g}\right)=\dot{m}_{g p} \\
& \frac{\partial}{\partial t}\left(\alpha_{p} \rho_{p}\right)+\nabla \cdot\left(\alpha_{p} \rho_{p} \vec{v}_{p}\right)=\dot{m}_{p g}
\end{aligned}
$$

where $\alpha, \rho$ and $\vec{v}$ represent the volume fraction, density, and velocity, respectively, $\dot{m}_{g p}$ and $\dot{m}_{p g}$ are the mass source terms generated by the heterogeneous reactions, and the subscripts $g$ and $p$ represent gas phase and particle phase, respectively.

The momentum equations for gas and solid phases are given by Equations (9) and (10):

$$
\begin{gathered}
\frac{\partial}{\partial t}\left(\alpha_{g} \rho_{g} \vec{v}_{g}\right)+\nabla \cdot\left(\alpha_{g} \rho_{g} \vec{v}_{g} \vec{v}_{g}\right)=-\alpha_{g} \nabla p+\nabla \cdot \overline{\bar{\tau}}_{g}+\alpha_{g} \rho_{g} \vec{g}+\dot{m}_{g p} \vec{v}_{g}+\beta\left(\vec{v}_{p}-\vec{v}_{g}\right) \\
\frac{\partial}{\partial t}\left(\alpha_{p} \rho_{p} \vec{v}_{p}\right)+\nabla \cdot\left(\alpha_{p} \rho_{p} \vec{v}_{p} \vec{v}_{p}\right)=-\alpha_{p} \nabla p-\nabla p_{p}+\nabla \cdot \overline{\bar{\tau}}_{p}+\alpha_{p} \rho_{p} \vec{g}+\dot{m}_{p g} \vec{v}_{p}+\beta\left(\vec{v}_{g}-\vec{v}_{p}\right)
\end{gathered}
$$

where $\beta$ is the drag coefficient between the gas phase and particle phase.

The energy conservation equations for gas and solid phases are given by Equations (11) and (12):

$$
\begin{gathered}
\frac{\partial}{\partial t}\left(\alpha_{g} \rho_{g} H_{g}\right)+\nabla \cdot\left(\alpha_{g} \rho_{g} \vec{v}_{g} H_{g}\right)=\nabla \cdot\left(\lambda_{g} \nabla T_{g}\right)+h_{g p}\left(T_{g}-T_{p}\right)+\dot{m}_{g p} H_{g} \\
\frac{\partial}{\partial t}\left(\alpha_{p} \rho_{p} H_{p}\right)+\nabla \cdot\left(\alpha_{p} \rho_{p} \vec{v}_{p} H_{p}\right)=\nabla \cdot\left(\lambda_{p} \nabla T_{p}\right)+h_{p g}\left(T_{p}-T_{g}\right)+\dot{m}_{p g} H_{p}
\end{gathered}
$$

where $H$ and $\lambda$ represent the specific enthalpy and the mixture thermal conductivity, respectively. $h_{g p}$ and $h_{p g}$ are the heat transfer coefficient between phases.

The species transport equations are solved for individual species in each phase, taking the forms of Equations (13) and (14):

$$
\begin{gathered}
\frac{\partial}{\partial t}\left(\alpha_{g} \rho_{g} Y_{g, i}\right)+\nabla \cdot\left(\alpha_{g} \rho_{g} Y_{g, i} \vec{v}_{g}\right)=-\nabla \cdot \alpha_{g} J_{g, i}+\dot{m}_{g, i} \\
\frac{\partial}{\partial t}\left(\alpha_{p} \rho_{p} Y_{p, i}\right)+\nabla \cdot\left(\alpha_{p} \rho_{p} Y_{p, i} \vec{v}_{p}\right)=\dot{m}_{p, i}
\end{gathered}
$$

where $J_{g, i}$ represents the diffusion flux of species $i$.

The stress tensors of the gas and solid phases are defined in Equations (15) and (16):

$$
\begin{gathered}
\overline{\bar{\tau}}_{g}=\alpha_{g} \mu_{g}\left[\nabla \vec{v}_{g}+\left(\nabla \vec{v}_{g}\right)^{T}\right]-\frac{2}{3} \alpha_{g} \mu_{g} \nabla \cdot \vec{v}_{g} \overline{\bar{I}} \\
\left.\overline{\bar{\tau}}_{p}=\alpha_{p} \mu_{p} \mid \nabla \vec{v}_{p}+\left(\nabla \vec{v}_{p}\right)^{T}\right]+\alpha_{p}\left(\xi_{p}-\frac{2}{3} \mu_{p}\right) \nabla \cdot \vec{v}_{p} \overline{\bar{I}}
\end{gathered}
$$

where $\mu_{g}$ and $\mu_{p}$ are the shear viscosities of gas phase and solid phase, respectively. $\xi_{p}$ is the bulk viscosity of solid phase.

The standard $k-\varepsilon$ turbulent model is adopted to describe the turbulence of gas phase $[64,67,68]$ :

$$
\frac{\partial}{\partial t}\left(\alpha_{g} \rho_{g} \mathcal{K}\right)+\nabla \cdot\left(\alpha_{g} \rho_{g} \vec{v}_{g} \mathcal{K}\right)=\nabla \cdot\left(\alpha_{g} \frac{\mu_{g t}}{\sigma_{\mathcal{K}}} \nabla \kappa\right)+\alpha_{g} G_{\kappa}-\alpha_{g} \rho_{g} \varepsilon+\alpha_{g} \rho_{g} \Pi_{\mathcal{K}}
$$




$$
\frac{\partial}{\partial t}\left(\alpha_{g} \rho_{g} \varepsilon\right)+\nabla \cdot\left(\alpha_{g} \rho_{g} \vec{v}_{g} \varepsilon\right)=\nabla \cdot\left(\alpha_{g} \frac{\mu_{g t}}{\sigma_{\varepsilon}} \nabla \varepsilon\right)+\alpha_{g} \frac{\varepsilon}{\mathcal{K}}\left(C_{1} G_{\mathcal{K}}-C_{2} \rho_{g} \varepsilon\right)+\alpha_{g} \rho_{g} \Pi_{\varepsilon}
$$

where $G_{\kappa}$ represents the production of turbulent kinetic energy, $\Pi_{\kappa}$ and $\Pi_{\varepsilon}$ are the turbulence exchange terms between phases.

The kinetic theory of granular flow is used for modeling the rheology of the particle phase [69]:

$$
\frac{\partial}{\partial t}\left(\alpha_{p} \rho_{p} \Theta\right)+\nabla \cdot\left(\alpha_{p} \rho_{p} \vec{v}_{p} \Theta\right)=\frac{2}{3}\left[\left(-p_{p} \overline{\bar{I}}+\overline{\bar{\tau}}_{p}\right): \nabla \vec{v}_{p}+\nabla \cdot\left(\Gamma_{\Theta} \nabla \Theta\right)-\gamma_{p}+\varphi_{p}\right]
$$

where $\Theta$ is the granular temperature reflecting the kinetic energy of solids random motion; $\Gamma_{\Theta}, \gamma_{p}$ and $\varphi_{p}$ represent the diffusion coefficient, the energy collisional dissipation, and the energy exchange between gas-solid phases, respectively.

The Gidaspow model, which can selectively calculate the gas-solid drag coefficient $\beta$ in the dilute or dense phases, is selected as the drag model in this study [70]:

$$
\beta=\left\{\begin{array}{l}
0.75 C_{D} \frac{\alpha_{p} \alpha_{g} \rho_{g}\left|\vec{v}_{p}-\vec{v}_{g}\right|}{d_{p}} \alpha_{g}^{-2.65},\left(\alpha_{g}>0.8\right) \\
150 \frac{\alpha_{p}^{2} \mu_{g}}{\alpha_{g} d_{p}^{2}}+1.75 \frac{\rho_{g} \alpha_{p}\left|\vec{v}_{p}-\vec{v}_{g}\right|}{d_{p}},\left(\alpha_{g} \leq 0.8\right)
\end{array}\right.
$$

\subsection{Chemical Reaction Models}

The solid phase consists of char, $\mathrm{CuO}, \mathrm{Cu}$ and $\mathrm{Al}_{2} \mathrm{O}_{3}$, and the gas phase consists of $\mathrm{CO}_{2}, \mathrm{H}_{2}, \mathrm{CO}$, $\mathrm{H}_{2} \mathrm{O}$ and $\mathrm{N}_{2}$. The reactions occurred in the fuel reactors involve heterogeneous reactions of gasification, homogeneous water gas shift (WGS) reaction and heterogeneous reduction reactions of oxygen carrier, i.e., Equations (1)-(5).The reaction rates follow the Arrhenius equation, and the pre-exponential factors and activation energy are acquired from the literature $[7,66,71]$. Table 1 lists the detailed formulas of the heterogeneous reaction rates.

Table 1. Rate parameters of the heterogeneous reactions occurred in the fuel reactor.

\begin{tabular}{cccc}
\hline No. & Reaction Rate Constant $\boldsymbol{k}$ & Reaction Rate $\boldsymbol{r}$ & Reference \\
\hline 1 & $k_{1}=2.07 \times 10^{4} \exp (-22000 / R T)$ & $r_{1}=k_{1} P_{\mathrm{H}}^{0.73}$ & {$[71]$} \\
2 & $k_{2}=1.12 \times 10^{5} \exp (-245000 / R T)$ & $r_{2}=k_{2} P_{\mathrm{CO}}^{0.31}$ & {$[71]$} \\
3 & $k_{3}=2.842 \times 10^{-2} \exp (-3961.5 / R T)$ & $r_{3}=k_{3}\left(Y_{\mathrm{CO}} Y_{\mathrm{H}_{2} \mathrm{O}}-Y_{\mathrm{CO}_{2}} Y_{\mathrm{H} 2} / K_{3 e q}\right)$ & {$[66]$} \\
4 & $k_{4}=1.54 \times 10^{-3} \exp (-20000 / R T)$ & $r_{4}=k_{4} C_{\mathrm{H}_{2}} \alpha_{p} Y_{\mathrm{CuO}} / r_{g, C u O}$ & {$[7]$} \\
5 & $k_{5}=2.21 \times 10^{-4} \exp (-11000 / R T)$ & $r_{5}=k_{5} C_{\mathrm{CO}}^{0.8} \alpha_{p} Y_{\mathrm{CuO}} / r_{g, C u O}$ & {$[7]$} \\
\hline
\end{tabular}

\subsection{Initial Conditions and Boundary Conditions}

A three-dimensional geometry is adopted in this simulation work. The finite volume method is used for the solution of the governing equations. The second-order upwind discretization is selected for all solutions. The time step of $1 \times 10^{-4} \mathrm{~s}$ and the convergence criterion of $1 \times 10^{-4}$ are applied for calculation. After mesh independent analysis, the grids with the size of $22 \mathrm{~mm} \times 22 \mathrm{~mm} \times 22 \mathrm{~mm}$ are adopted in the most zones while the mesh refinements are applied near the inlets.

The velocity inlet and outflow are chosen as the boundary conditions of the inlet and outlet, respectively. At the walls, the no-slip condition is considered for both of the gas and solid phases. Initially, the particles of oxygen carrier accumulate in the fuel reactor under $\mathrm{N}_{2}$ atmosphere. The initial volume fraction of solid phase is set to be 0.55 with the bed height of $1.1 \mathrm{~m}$. The selected oxygen carrier is the so-called Cu14Al-I which contains $14 \mathrm{wt} \%$ of $\mathrm{CuO}$ as the active component and $86 \mathrm{wt} \%$ of inert $\mathrm{Al}_{2} \mathrm{O}_{3}[61,62,72]$. The detailed model parameters and initial conditions used in the simulations are summarized in Table 2. 
Table 2. Model parameters and initial conditions applied to the simulations.

\begin{tabular}{ccc}
\hline Description & Unit & Value \\
\hline Reactor diameter & $\mathrm{m}$ & 0.22 \\
Reactor height & $\mathrm{m}$ & 2 \\
Mean particle density & $\mathrm{kg} / \mathrm{m}^{3}$ & 1560 \\
Mean particle diameter & $\mathrm{mm}$ & 0.5 \\
Initial volume fraction of solid phase & - & 0.55 \\
Maximum packing of solid phase & - & 0.64 \\
Initial bed height & $\mathrm{m}$ & 1.1 \\
Char feed rate & $\mathrm{kg} / \mathrm{h}$ & 1.6 \\
Inlet steam temperature & $\mathrm{K}$ & 1073 \\
Fluidizing number & - & 6 \\
Inlet boundary condition & - & velocity-inlet \\
Outlet boundary condition & - & outflow \\
Time step size & $\mathrm{s}$ & $10^{-4}$ \\
Convergence criteria & - & $10^{-4}$ \\
\hline
\end{tabular}

\section{Results and Discussion}

\subsection{Flow Patterns and Composition Distributions}

Initially, the particles of oxygen carrier suspend in the space of inert gas $\left(\mathrm{N}_{2}\right)$. When the calculation is started, the stream of gasification agent $\left(\mathrm{H}_{2} \mathrm{O}\right)$ is injected into the reactor from the bottom distributor, while the fuel char is transported by $\mathrm{N}_{2}$ into the inlet in the side of the reactor.

Most of the bubble features such as formation, rise, and collapse are observed in Figure 3a, where the blue color illustrates the pure gas atmosphere and the red color represents the maximum solids holdup. Meanwhile, we can see the bed expansion due to the existence of bubbles. The computed flow patterns predict a global gas-solid mixing in the bed. The axial molar fraction distributions of gas compositions are presented in Figure $3 b, c$, where the blue and red colors represent the minimum and maximum species concentrations, respectively. Some differences can be found between the fluidized regime and freeboard region. In the fluidized regime, $\mathrm{CO}_{2}$ is generated from the chemical looping reaction of one of the gasification products $\mathrm{CO}$ with the oxygen carrier. Generally, the concentration of $\mathrm{CO}_{2}$ increases along the bed height. However, the average of $\mathrm{CO}_{2}$ concentration within the bubbles is smaller than that at the nearby emulsion zone, implying that the presence of bubbles has a negative effect on the sufficient contact and reaction of gas-solid reactive components. On the other side, the $\mathrm{CO}_{2}$ concentration in the freeboard keeps nearly constant, reflecting a serious dent of heterogeneous reactions in this region due to the lack of particle phase. On the other hand, the molar fraction of $\mathrm{H}_{2} \mathrm{O}$ goes down with the reactor height in the fluidized regime due to the continuous production of $\mathrm{CO}_{2}$, and it almost keeps constant in the freeboard. Compared to the sole role as the product in gas-fueled $\mathrm{CLC}, \mathrm{H}_{2} \mathrm{O}$ in iG-CLC plays the roles of both the chemical looping product and the gasification agent. Hence, different with the continues increase of concentration along the bed height for gas-fueled CLC [61,62], the concentration of $\mathrm{H}_{2} \mathrm{O}$ for iG-CLC presents a downward trend due to the consumption from char gasification. Figure $3 \mathrm{~d}$ gives the mass fraction distribution of char, which presents a low concentration in the fluidized regime, indicating the char is mostly consumed from the gasification reactions. It should be noted that because the fuel reactor model developed in this study doesn't consider the regular deslagging, it will inevitably lead to a certain degree of accumulation of unreacted char with the process of calculation. 


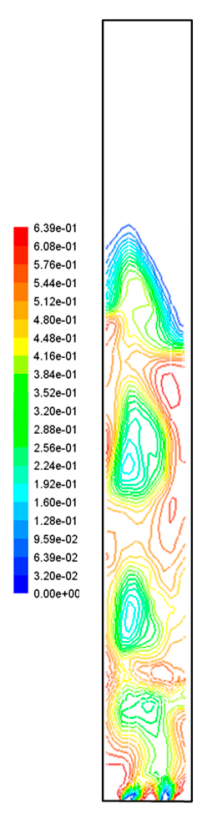

(a) Solids holdup

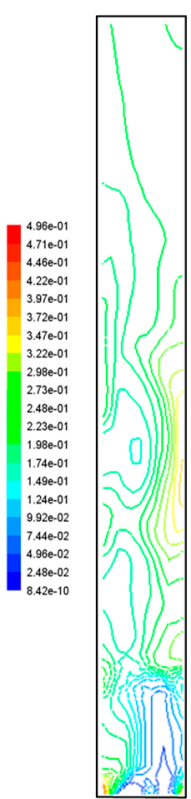

(b) $\mathrm{CO}_{2}$

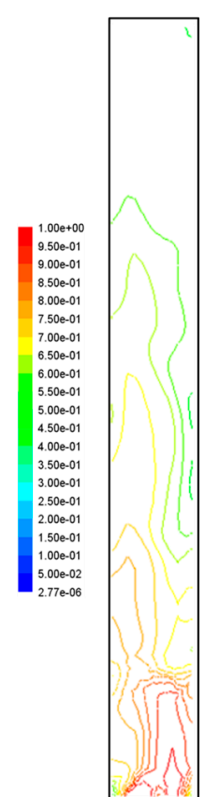

(c) $\mathrm{H}_{2} \mathrm{O}$

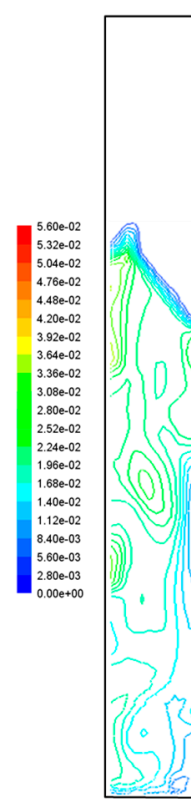

(d) Char

Figure 3. Axial $(x=0)$ distributions of flow patterns and gas-solid concentrations. (a) Solids holdup; (b) $\mathrm{CO}_{2}$ molar fraction in gas phase; (c) $\mathrm{H}_{2} \mathrm{O}$ molar fraction in gas phase; (d) Char mass fraction in solid phase.

Generally, the bubbles in the BFB fuel reactor can effectively promote particle motions, and hence the mixing with the gas phase. However, in contrast, the bubbles capture and envelop a part of the intermediate reactive gases from gasification, which will cause the isolation of the reactive gases and the oxygen carrier particles, and further limit the chemical looping reaction efficiency. [61,73].

Figure 4 displays the variations in the molar fractions of gas compositions with time at the outlet of the fuel reactor. The composition distribution can be categorized into three periods, according to the variation trend with computation time. In the first period, i.e., when the computation time is less than $3.2 \mathrm{~s}$, the molar fraction of $\mathrm{N}_{2}$ always equals to one while the other gas compositions remain zero, indicating the calculation process has not yet reached the outlet. Thus, the first stage can be called as the initialization stage. In the second period, i.e., when the computation time is between the range of $3.2 \mathrm{~s}$ to $5 \mathrm{~s}$, the concentrations of all the gas compositions present rapid time-varying characteristics. Specifically, the molar fraction of $\mathrm{N}_{2}$ decreases rapidly, while the other compositions increase fast. According to the variation characteristics, this period can be referred to as the transition stage. When the downward concentration of $\mathrm{N}_{2}$ reaches the minimum, i.e., when the computation time is larger than $5 \mathrm{~s}$, it comes to the third period, so called the stable stage. In this period, all of the gas concentrations reach quasi-equilibrium state, just with slight fluctuations. The average values of the gas compositions in this stage are obtained to be about $3.0 \%$ for $\mathrm{H}_{2}, 7.2 \%$ for $\mathrm{CO}, 54.0 \%$ for $\mathrm{H}_{2} \mathrm{O}$, and $22.1 \%$ for $\mathrm{CO}_{2}$. In conclusion, based upon the time-varying characteristics, the calculation should ensure reach the stable stage where the calculation results can be acquired with the time-averaging method. 


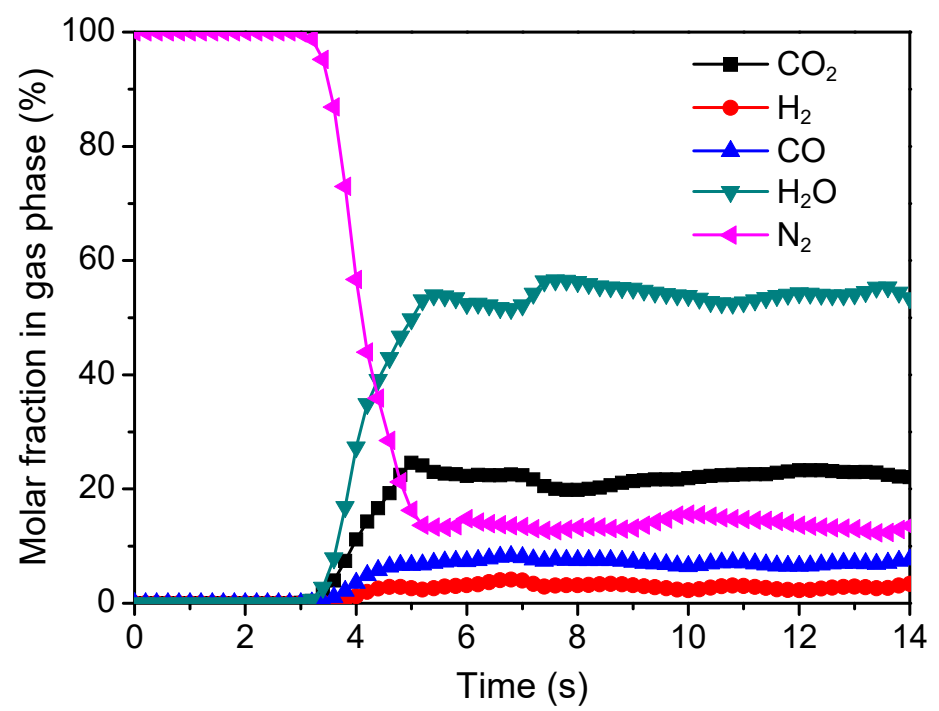

Figure 4. Variations of the gas molar fractions with time at the fuel reactor outlet.

\subsection{Model Validation and Reaction Performance Evaluation}

Before further modeling research, the simulation of steam-char gasification with sand as the bed material has been carried out for the model validation and providing reference to the reaction performance evaluation of iG-CLC. Figure 5 shows a comparison of the computed exhaust concentrations from steam-char gasification reaction over sand with the previous data [66]. The calculated gas concentrations agree well with the previous data. As a whole, the relative error of calculation is less than $8 \%$, which illustrates the reasonability of the simulation results and the validity of the present model.

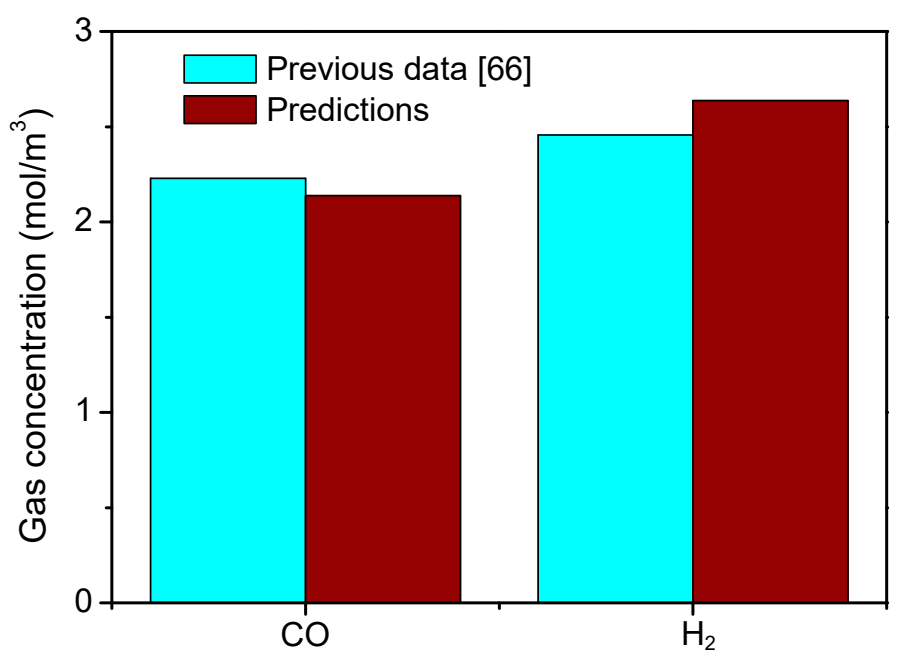

Figure 5. Comparison of the computed exhaust concentrations from steam-char gasification reaction over sand with the previous data: $\mathrm{T}_{0}=1173 \mathrm{~K}, \mathrm{U} / \mathrm{U}_{\mathrm{mf}}=4.5$.

Figure 6 presents a comparison of $\mathrm{N}_{2}$-excluded flue gas concentrations (dry basis) with different solid materials. It can be found that the flue gas concentrations change a lot from gasification to iG-CLC. The mean concentrations of $\mathrm{H}_{2}$ and $\mathrm{CO}$ at the outlet for steam-char gasification over sand are $52.3 \%$ and $43.2 \%$, which decrease to $9.4 \%$ and $22.5 \%$ for char-fueled iG-CLC, respectively. Meanwhile, the $\mathrm{CO}_{2}$ concentration increase from $4.5 \%$ for gasification to $68.1 \%$ for iG-CLC. Through the comparison we can conclude that most of the intermediate gasification products have been consumed by the oxygen carrier during the process of iG-CLC. 


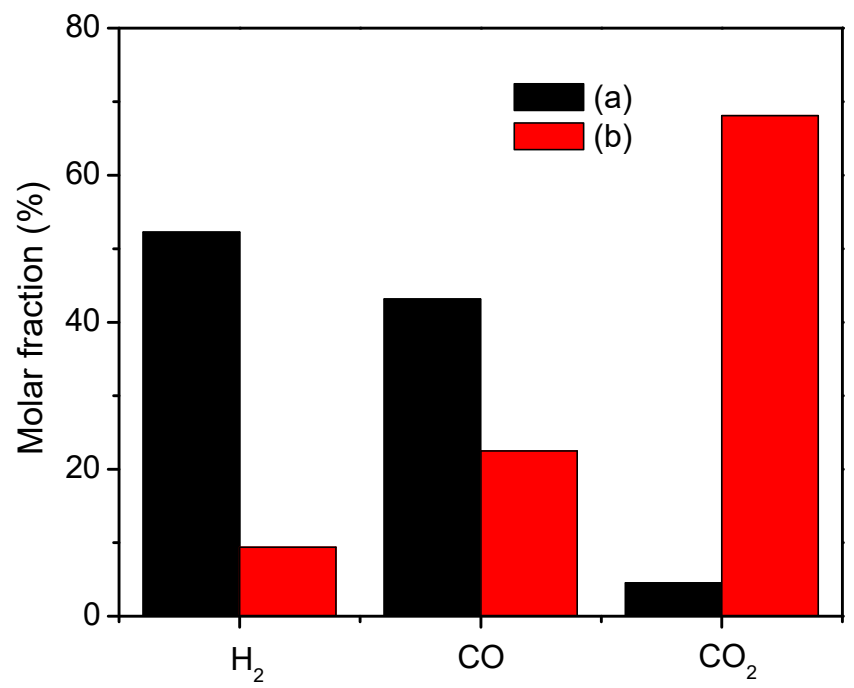

Figure 6. Comparison of $\mathrm{N}_{2}$-excluded flue gas concentrations (dry basis). (a) Gas concentrations for gasification over sand at the outlet; (b) Gas concentrations for iG-CLC at the outlet.

\subsection{Patterns of Gas-Solid Reactions}

The reaction process in the iG-CLC process is complex because it involves not only the matching relation between the char gasification and the subsequent chemical-looping reactions of the gasification products with the oxygen carrier, but also the coupling relationship between the flow and reaction behaviors. Hence, the in-depth understanding of the iG-CLC reaction mechanism has significant meaning for the further development of iG-CLC applications. Figure 7 displays the axial distributions of heterogeneous reactions in the fuel reactor, where the color range from blue to red illustrates the change of reaction rate from minimum to maximum.

\subsubsection{Gasification Reactions of Char}

Figure $7 \mathrm{a}, \mathrm{b}$ shows the gasification reactions of $\mathrm{C}(\mathrm{s})-\mathrm{H}_{2} \mathrm{O}$ and $\mathrm{C}(\mathrm{s})-\mathrm{CO}_{2}$. It can be seen that the reaction rate of $\mathrm{C}(\mathrm{s})-\mathrm{CO}_{2}$ is much lower than that of $\mathrm{C}(\mathrm{s})-\mathrm{H}_{2} \mathrm{O}$, which is believed to be mainly related to the much lower reactivity of $\mathrm{CO}_{2}$ than $\mathrm{H}_{2} \mathrm{O}$ with char, and also the lower concentration. This demonstrates that the steam is a better candidate as the gasification agent during the operation temperature range of iG-CLC. On the other hand, by comparison of Figures $3 c$ and $7 \mathrm{a}$, we can observe a close bond between the gasification reaction rate of $\mathrm{C}(\mathrm{s})-\mathrm{H}_{2} \mathrm{O}$ and the concentration distribution of $\mathrm{H}_{2} \mathrm{O}$. The $\mathrm{C}(\mathrm{s})-\mathrm{H}_{2} \mathrm{O}$ rate drops along the bed height because the concentration and further the partial pressure of $\mathrm{H}_{2} \mathrm{O}$ decline during its ascent. On the contrary, from Figures $3 \mathrm{~b}$ and $7 \mathrm{~b}$, it can be found that the $\mathrm{C}(\mathrm{s})-\mathrm{CO}_{2}$ rate increases with the bed height as more $\mathrm{CO}_{2}$ is generated in the higher area.

\subsubsection{Chemical-Looping Reactions of Oxygen Carrier}

Figure $7 \mathrm{c}, \mathrm{d}$ displays the chemical-looping reactions of the intermediate gasification products and the $\mathrm{Cu}$-based oxygen carrier. By comparison with Figure 7a, we can observe that the reaction rates of $\mathrm{CuO}(\mathrm{s})-\mathrm{CO}$ and $\mathrm{CuO}(\mathrm{s})-\mathrm{H}_{2}$ are at the same level with the gasification rate of $\mathrm{C}(\mathrm{s})-\mathrm{H}_{2} \mathrm{O}$. This reflects the high reactivity of the $\mathrm{Cu}$-based oxygen carrier selected, which can ensure the timely conversion of the gasification products. Besides, by integrating the rate equations shown in Table 1, we can further find that the in-time consumption of the intermediate gasification products can guarantee the concentration of gasification agents, and further promote the front-end gasification rate. This illustrates the positive role of the direct mixing of oxygen carrier and fuel in the global reaction rate of the iG-CLC approach, by considering that the $\mathrm{C}(\mathrm{s})-\mathrm{H}_{2} \mathrm{O}$ gasification is the rate-determining step of all the reactions $[23,63,74]$. In addition, according to Figures 3 and 7, we can further find that the chemical-looping reaction rates of $\mathrm{CuO}(\mathrm{s})-\mathrm{H}_{2}$ and $\mathrm{CuO}(\mathrm{s})-\mathrm{CO}$ are also related to the flow patterns. Specifically, in the area where bubbles 
exist, the chemical looping rates are lower, which will further lead to a relatively low combustion efficiency. This observation demonstrates the negative effect of bubbles on the sufficient contact and reaction of gas-solid components, as mentioned in Section 3.1.

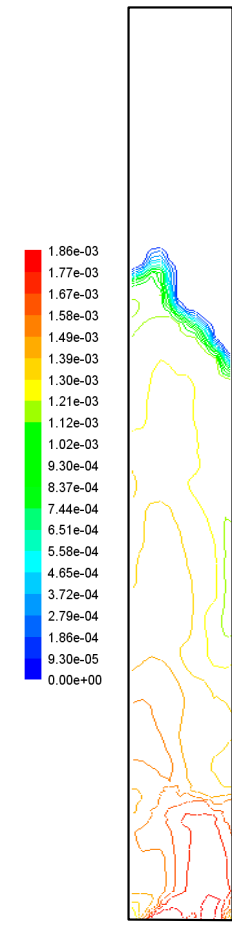

(a) $\mathrm{C}(\mathrm{s})-\mathrm{H}_{2} \mathrm{O}$

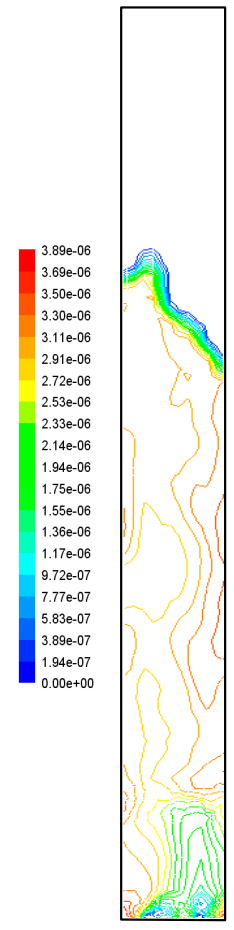

(b) $\mathrm{C}(\mathrm{s})-\mathrm{CO}_{2}$

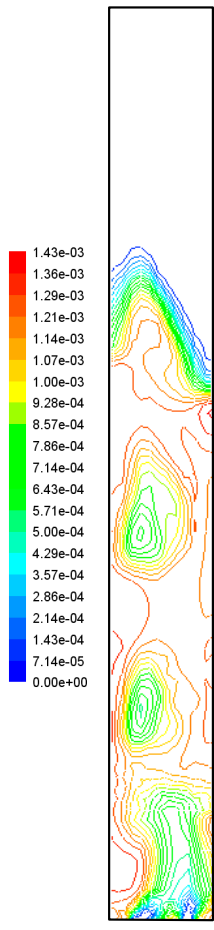

(c) $\mathrm{CuO}(\mathrm{s})-\mathrm{CO}$

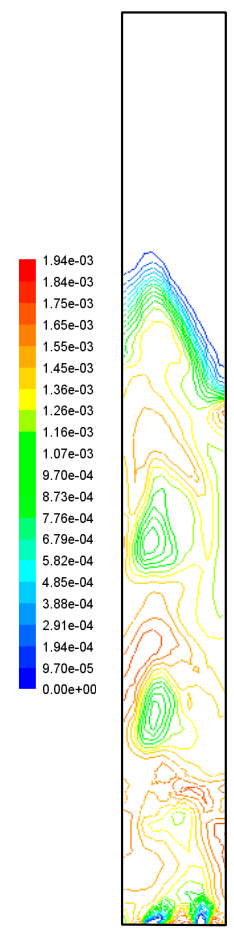

(d) $\mathrm{CuO}(\mathrm{s})-\mathrm{H}_{2}$

Figure 7. Distributions of heterogeneous reaction rates $\left(\mathrm{H}_{\mathrm{b}}=1.1 \mathrm{~m}, \mathrm{Qc}=1.6 \mathrm{~kg} / \mathrm{h}, \mathrm{U} / \mathrm{U}_{\mathrm{mf}}=6\right.$, $\left.\mathrm{T}_{\mathrm{b}}=1073 \mathrm{~K}\right)$. (a) $\mathrm{C}(\mathrm{s})-\mathrm{H}_{2} \mathrm{O}$ rate; (b) $\mathrm{C}(\mathrm{s})-\mathrm{CO}_{2}$ rate; (c) $\mathrm{CuO}(\mathrm{s})-\mathrm{CO}$ rate; (d) $\mathrm{CuO}(\mathrm{s})-\mathrm{H}_{2}$ rate.

\subsection{Influence of Solids Inventory}

The solids inventory of the fuel reactor is one of the most important operating variables influencing the performance of a CLC system. Hence, three different cases have been carried out to study the influence of solids inventory (represented by the initial bed height) on the iG-CLC performance.

Figure 8 exhibits the distributions of $\mathrm{N}_{2}$-excluded flue gas concentrations (dry basis) in different solids inventories. The concentrations of $\mathrm{H}_{2}$ and $\mathrm{CO}$ at the outlet decrease with the increase of solids inventory while it is on the contrary for $\mathrm{CO}_{2}$. The average molar fractions of $\mathrm{H}_{2}$ and $\mathrm{CO}$ are $11.1 \%$ and $22.4 \%$ for the initial bed height of $0.9 \mathrm{~m}$, and decrease to $8.2 \%$ and $20.8 \%$ for $1.3 \mathrm{~m}$, respectively. The mean value of $\mathrm{CO}_{2}$ fraction is $64.4 \%$ at the bed height of $0.9 \mathrm{~m}$, which increases to $71.1 \%$ at that of $1.3 \mathrm{~m}$. The results illustrate that solids inventory promotes the increase of the fuel conversion and $\mathrm{CO}_{2}$ concentration. But it should be pointed out that the increase of solid inventory will also increase the system size and operation cost. Therefore, in order to select a suitable solid inventory, the comprehensive consideration of combustion efficiency and investment cost is necessary.

In addition, compared to our previous studies on the gas-fueled CLC [62], the influence of solids inventory on the fuel gas conversion is far smaller in the iG-CLC process. This is mainly because that in gas-fueled CLC, the increase of solids inventory can directly increase the reaction time and contact probability between the fuel gas and oxygen carrier. However, in the iG-CLC process, the chemical looping reaction rates between the oxygen carrier and the intermediate gasification products are mainly limited by the front-end slow reaction of char gasification, which further weakens the facilitation of solids inventory. 


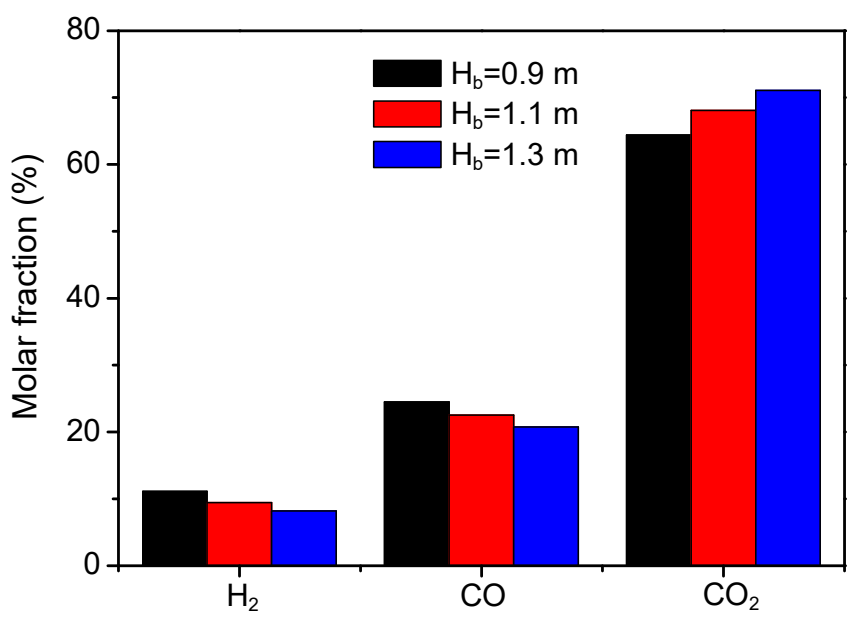

Figure 8. Distributions of $\mathrm{N}_{2}$-excluded flue gas concentrations (dry basis) in different solids inventories.

\subsection{Influence of Fluidizing Number}

The gas stream of a fuel reactor is significant to the iG-CLC approach because it not only undertakes the task of carrying particles for flow and mixing, but also contains the reactive components for the reaction. Hence, it is very interesting to understand the effects of the gas stream (represented by the fluidizing number) on the iG-CLC performance. The fluidizing number is defined as the ratio between the superficial gas velocity $U$ and the minimum fluidizing velocity $U_{m f}$ [75-78]. In this study, three different fluidizing numbers $\mathrm{U} / \mathrm{U}_{\mathrm{mf}}$ ranging from five to seven are selected for calculation.

Figure 9 shows the comparison of the $\mathrm{N}_{2}$-excluded flue gas concentrations (dry basis) with different fluidizing numbers. It can be found that the increase of fluidizing number leads to a decline of $\mathrm{CO}_{2}$ concentration, and it is just the reverse for $\mathrm{H}_{2}$ and $\mathrm{CO}$. The $\mathrm{CO}_{2}$ concentration decreases from $69.5 \%$ to $66.2 \%$ as the velocity ratio $\mathrm{U} / \mathrm{U}_{\mathrm{mf}}$ increases from five to seven. The concentrations of $\mathrm{H}_{2}$ and CO increase from $8.7 \%$ and $21.8 \%$ to $10.2 \%$ and $23.6 \%$, respectively. The change of gas conversions in different superficial gas velocities is mainly because of the variation in flow patterns, according to the previous literature [79]. Firstly, larger fluidizing gas velocities lead to shorter residence time of gas stream in the bed. In addition, the size of a bubble grows at a higher gas velocity, which weakens the gas-solid contact. However, similar to the observations mentioned in Section 3.4, the influence of the fluidizing number on the iG-CLC performance is much smaller than that on the gas-fueled CLC performance [61] because of the restriction from the char gasification rate.

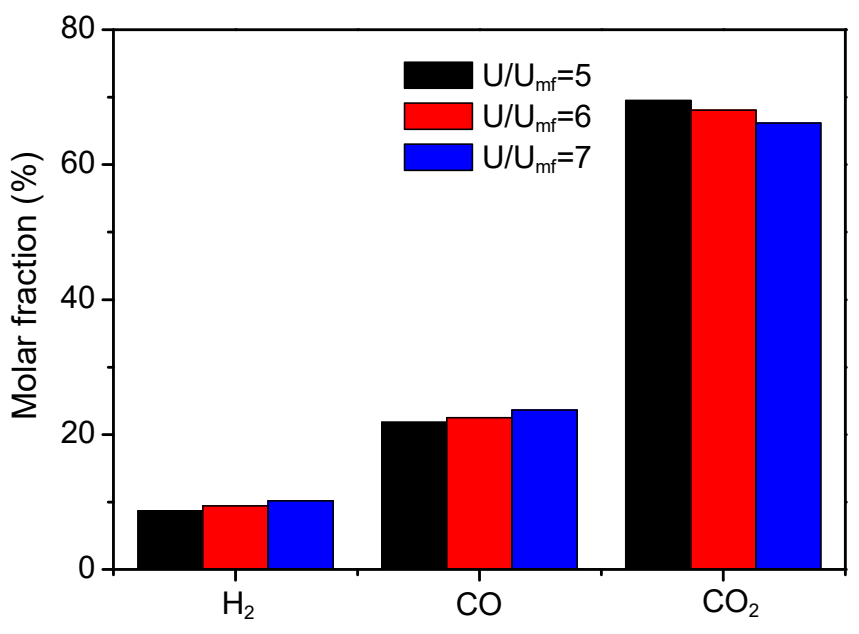

Figure 9. Distributions of $\mathrm{N}_{2}$-excluded flue gas concentrations (dry basis) in different fluidizing numbers. 


\section{Conclusions}

A comprehensive three-dimensional CFD model is built to predict the char-fueled iG-CLC process in a BFB fuel reactor. The simulation results reveal the complex process mechanism of the iG-CLC approach, involving the coupling of hydrodynamics, char gasification, and chemical looping reactions of oxygen carrier, and its difference with gas-fueled CLC in terms of the adaptability to the operation conditions. The following conclusions can be drawn from this study:

(1) In the fluidized regime, most of the intermediate products $\left(\mathrm{CO}\right.$ and $\left.\mathrm{H}_{2}\right)$ from gasification are converted to $\mathrm{CO}_{2}$ and $\mathrm{H}_{2} \mathrm{O}$ by the oxygen carrier. However, the presence of bubble phase shows negative influence on the sufficient contact and reaction between gas-solid reactive components. In the freeboard region, the gas concentrations nearly keep constant because of the lack of solid phase in this region.

(2) The $\mathrm{N}_{2}$-excluded $\mathrm{CO}_{2}$ concentration (dry basis) at the outlet for steam-char gasification over sand is $4.5 \%$, which increases to $68.1 \%$ for iG-CLC of char. The concentrations of $\mathrm{H}_{2}$ and CO decrease from $52.3 \%$ and $43.2 \%$ to $9.4 \%$ and $22.5 \%$, respectively. This implies that the Cu-based oxygen carrier selected is highly reactive to consume the intermediate gasification products during the iG-CLC process.

(3) The gasification is the rate-determining step of all the reactions. In addition, the performance of the reaction is closely correlated with the flow patterns and the concentration distributions of components.

(4) A higher $\mathrm{CO}_{2}$ concentration at the outlet can be achieved by increasing the solids inventory or decreasing the fluidizing number, which may cause the change of flow patterns such as gas residence time and bubble size. However, the effects of the solids inventory and fluidizing number on the iG-CLC performance are much smaller than those on the gas-fueled CLC because of the restriction from the front-end slow reaction of char gasification.

The results of these simulation investigations provide a deep understanding of the hydrodynamics and reaction characteristics of the iG-CLC process, which would be hard to come by under the current experimental conditions. Therefore, the present study provides important guidance for the design and application of future commercial iG-CLC power plants.

Author Contributions: Conceptualization, X.W.; supervision, B.J., Y.Z. and B.Z.; investigation, X.W.; formal analysis, X.W. and X.L.; writing—original draft preparation, X.W.; writing-review and editing, X.L. and Y.Z.

Funding: This financial supports by the National Natural Science Foundation of China (51806035), the Natural Science Foundation of Jiangsu Province (BK20170669), and the Fundamental Research Funds for the Central Universities (2242018K40117) are gratefully acknowledged.

Conflicts of Interest: The authors declare no conflict of interest.

\section{References}

1. Abanades, J.C.; Rubin, E.S.; Anthony, E.J. Sorbent cost and performance in $\mathrm{CO}_{2}$ capture systems. Ind. Eng. Chem. Res. 2004, 43, 3462-3466. [CrossRef]

2. Buhre, B.J.; Elliott, L.K.; Sheng, C.D.; Gupta, R.P.; Wall, T.F. Oxy-fuel combustion technology for coal-fired power generation. Prog. Energy Combust. 2005, 31, 283-307. [CrossRef]

3. Lyngfelt, A.; Leckner, B.; Mattisson, T. A fluidized-bed combustion process with inherent $\mathrm{CO}_{2}$ separation; application of chemical-looping combustion. Chem. Eng. Sci. 2001, 56, 3101-3113. [CrossRef]

4. Li, F.; Fan, L.S. Clean coal conversion processes-progress and challenges. Energy Environ. Sci. 2008, 1, 248-267. [CrossRef]

5. Toftegaard, M.B.; Brix, J.; Jensen, P.A.; Glarborg, P.; Jensen, A.D. Oxy-fuel combustion of solid fuels. Prog. Energy Combust. 2010, 36, 581-625. [CrossRef]

6. Fan, L.S.; Zeng, L.; Wang, W.; Luo, S. Chemical looping processes for $\mathrm{CO}_{2}$ capture and carbonaceous fuel conversion-prospect and opportunity. Energy Environ. Sci. 2012, 5, 7254-7280. [CrossRef] 
7. de Diego, L.F.; García-Labiano, F.; Gayán, P.; Celaya, J.; Palacios, J.M.; Adánez, J. Operation of a 10 kW th chemical-looping combustor during $200 \mathrm{~h}$ with a $\mathrm{CuO}-\mathrm{Al}_{2} \mathrm{O}_{3}$ oxygen carrier. Fuel 2007, 86, 1036-1045. [CrossRef]

8. Forero, C.R.; Gayán, P.; de Diego, L.F.; Abad, A.; García-Labiano, F.; Adánez, J. Syngas combustion in a 500 Wth Chemical-Looping Combustion system using an impregnated Cu-based oxygen carrier. Fuel Process. Technol. 2009, 90, 1471-1479. [CrossRef]

9. Mattisson, T.; Järdnäs, A.; Lyngfelt, A. Reactivity of some metal oxides supported on alumina with alternating methane and oxygen application for chemical-looping combustion. Energy Fuels 2003, 17, 643-651. [CrossRef]

10. Jin, H.; Ishida, M. A new type of coal gas fueled chemical-looping combustion. Fuel 2004, 83, $2411-2417$. [CrossRef]

11. Abad, A.; Mattisson, T.; Lyngfelt, A.; Rydén, M. Chemical-looping combustion in a 300W continuously operating reactor system using a manganese-based oxygen carrier. Fuel 2006, 85, 1174-1185. [CrossRef]

12. Adánez, J.; Dueso, C.; de Diego, L.F.; García-Labiano, F.; Gayán, P.; Abad, A. Methane combustion in a $500 \mathrm{~W}_{\text {th }}$ chemical-looping combustion system using an impregnated Ni-based oxygen carrier. Energy Fuels 2008, 23, 130-142. [CrossRef]

13. Kolbitsch, P.; Bolhàr-Nordenkampf, J.; Pröll, T.; Hofbauer, H. Operating experience with chemical looping combustion in a 120kW dual circulating fluidized bed (DCFB) unit. Int. J. Greenh. Gas Control 2010, 4, 180-185. [CrossRef]

14. Hamers, H.P.; Gallucci, F.; Cobden, P.D.; Kimball, E.; van Sint Annaland, M. A novel reactor configuration for packed bed chemical-looping combustion of syngas. Int. J. Greenh. Gas Control 2013, 16, 1-12. [CrossRef]

15. Ma, J.; Zhao, H.; Tian, X.; Wei, Y.; Zhang, Y.; Zheng, C. Continuous Operation of Interconnected Fluidized Bed Reactor for Chemical Looping Combustion of $\mathrm{CH}_{4}$ Using Hematite as Oxygen Carrier. Energy Fuels 2015, 29, 3257-3267. [CrossRef]

16. Cao, Y.; Pan, W.P. Investigation of Chemical looping combustion by solid fuels: 1 Process analysis. Energy Fuels 2006, 20, 1836-1844. [CrossRef]

17. Leion, H.; Mattisson, T.; Lyngfelt, A. Solid fuels in chemical-looping combustion. Int. J. Greenh. Gas Control 2008, 2, 180-193. [CrossRef]

18. Fan, L.S.; Li, F. Chemical looping technology and its fossil energy conversion applications. Ind. Eng. Chem. Res. 2010, 49. [CrossRef]

19. Abad, A.; Gayán, P.; de Diego, L.F.; García-Labiano, F.; Adánez, J. Fuel reactor modelling in chemical-looping combustion of coal: 1. Model formulation. Chem. Eng. Sci. 2013, 87, 277-293. [CrossRef]

20. Cuadrat, A.; Abad, A.; Gayán, P.; de Diego, L.F.; García-Labiano, F.; Adánez, J. Theoretical approach on the CLC performance with solid fuels: Optimizing the solids inventory. Fuel 2012, 97, 536-551. [CrossRef]

21. García-Labiano, F.; de Diego, L.F.; Gayán, P.; Abad, A.; Adánez, J. Fuel reactor modelling in chemical-looping combustion of coal: 2-simulation and optimization. Chem. Eng. Sci. 2013, 87, 173-182. [CrossRef]

22. Adánez, J.; Abad, A.; Mendiara, T.; Gayán, P.; de Diego, L.F.; García-Labiano, F. Chemical looping combustion of solid fuels. Prog. Energy Combust. 2018, 65, 6-66. [CrossRef]

23. Xiao, R.; Song, Q.; Song, M.; Lu, Z.; Zhang, S.; Shen, L. Pressurized chemical-looping combustion of coal with an iron ore-based oxygen carrier. Combust. Flame 2010, 157, 1140-1153. [CrossRef]

24. Berguerand, N.; Lyngfelt, A. Design and operation of a $10 \mathrm{~kW}_{\text {th }}$ chemical-looping combustor for solid fuels-testing with South African coal. Fuel 2008, 87, 2713-2726. [CrossRef]

25. Berguerand, N.; Lyngfelt, A. The use of petroleum coke as fuel in a $10 \mathrm{~kW}_{\text {th }}$ chemical-looping combustor. Int. J. Greenh. Gas Control 2008, 2, 169-179. [CrossRef]

26. Shen, L.H.; Wu, J.H.; Xiao, J. Experiments on chemical looping combustion of coal with a NiO based oxygen carrier. Combust. Flame 2009, 156, 721-728. [CrossRef]

27. Bayham, S.; McGiveron, O.; Tong, A.; Chung, E.; Kathe, M.; Wang, D.; Zeng, L.; Fan, L.S. Parametric and dynamic studies of an iron-based $25-\mathrm{kW}_{\text {th }}$ coal direct chemical looping unit using sub-bituminous coal. Appl. Energy 2015, 145, 354-363. [CrossRef]

28. Linderholm, C.; Schmitz, M. Chemical-looping combustion of solid fuels in a $100 \mathrm{~kW}$ dual circulating fluidized bed system using iron ore as oxygen carrier. J. Environ. Chem. Eng. 2016, 4, 1029-1039. [CrossRef]

29. Ma, J.; Zhao, H.; Tian, X.; Wei, Y.; Rajendran, S.; Zhang, Y.; Bhattacharya, S.; Zheng, C. Chemical looping combustion of coal in a $5 \mathrm{~kW}_{\text {th }}$ interconnected fluidized bed reactor using hematite as oxygen carrier. Appl. Energy 2015, 157, 304-313. [CrossRef] 
30. Pérez-Vega, R.; Abad, A.; García-Labiano, F.; Gayán, P.; de Diego, L.F.; Adánez, J. Coal combustion in a $50 \mathrm{~kW}_{\text {th }}$ Chemical Looping Combustion unit: Seeking operating conditions to maximize $\mathrm{CO}_{2}$ capture and combustion efficiency. Int. J. Greenh. Gas Control 2016, 50, 80-92. [CrossRef]

31. Ströhle, J.; Orth, M.; Epple, B. Design and operation of a $1 \mathrm{MW}_{\text {th }}$ chemical looping plant. Appl. Energy 2014, 113, 1490-1495. [CrossRef]

32. Thon, A.; Kramp, M.; Hartge, E.-U.; Heinrich, S.; Werther, J. Operational experience with a system of coupled fluidized beds for chemical looping combustion of solid fuels using ilmenite as oxygen carrier. Appl. Energy 2014, 118, 309-317. [CrossRef]

33. Xiao, R.; Chen, L.; Saha, C.; Zhang, S.; Bhattacharya, S. Pressurized chemical-looping combustion of coal using an iron ore as oxygen carrier in a pilot-scale unit. Int. J. Greenh. Gas Control 2012, 10, 363-373. [CrossRef]

34. Wang, X.; Jin, B.; Zhu, X.; Liu, H. Experimental Evaluation of a Novel $20 \mathrm{~kW}_{\text {th }}$ in Situ Gasification Chemical Looping Combustion Unit with an Iron Ore as the Oxygen Carrier. Ind. Eng. Chem. Res. 2016, 55, 11775-11784. [CrossRef]

35. Cheng, M.; Sun, H.; Li, Z.; Cai, N. Annular carbon stripper for chemical-looping combustion of coal. Ind. Eng. Chem. Res. 2017, 56, 1580-1593. [CrossRef]

36. Wang, P.; Means, N.; Howard, B.H.; Shekhawat, D.; Berry, D. The reactivity of CuO oxygen carrier and coal in Chemical-Looping with Oxygen Uncoupled (CLOU) and In-situ Gasification Chemical-Looping Combustion (iG-CLC). Fuel 2018, 217, 642-649. [CrossRef]

37. Fan, L.S. Chemical Looping Systems for Fossil Energy Conversions; John Wiley \& Sons: Hoboken, NJ, USA, 2011.

38. Adamczyk, W.P.; Bialecki, R.A.; Ditaranto, M.; Gladysz, P.; Haugen, N.E.L.; Katelbach-Wozniak, A.; Klimanek, A.; Sladek, S.; Szlek, A.; Wecel, G. CFD modeling and thermodynamic analysis of a concept of a MILD-OXY combustion large scale pulverized coal boiler. Energy 2017, 140, 1305-1315. [CrossRef]

39. Liu, B.; Papadikis, K.; Gu, S.; Fidalgo, B.; Longhurst, P.; Li, Z.; Kolios, A. CFD modelling of particle shrinkage in a fluidized bed for biomass fast pyrolysis with quadrature method of moment. Fuel Process. Technol. 2017, 164, 51-68. [CrossRef]

40. Wu, Y.; Liu, D.; Duan, L.; Ma, J.; Xiong, J.; Chen, X. Three-dimensional CFD simulation of oxy-fuel combustion in a circulating fluidized bed with warm flue gas recycle. Fuel 2018, 216, 596-611. [CrossRef]

41. Nam, H.; Rodriguez-Alejandro, D.A.; Adhikari, S.; Brodbeck, C.; Taylor, S.; Johnson, J. Experimental investigation of hardwood air gasification in a pilot scale bubbling fluidized bed reactor and CFD simulation of jet/grid and pressure conditions. Energy Convers. Manag. 2018, 168, 599-610. [CrossRef]

42. Deng, Z.G.; Xiao, R.; Jin, B.S.; Song, Q.L.; Huang, H. Multiphase CFD modeling for a chemical looping combustion process (fuel reactor). Chem. Eng. Technol. 2008, 31, 1754-1766. [CrossRef]

43. Jung, J.; Gamwo, I. Multiphase CFD-based models for chemical looping combustion process: Fuel reactor modeling. Powder Technol. 2008, 183, 401-409. [CrossRef]

44. Jin, B.; Xiao, R.; Deng, Z.; Song, Q. Computational fluid dynamics modeling of chemical looping combustion process with calcium sulphate oxygen carrier. Int. J. Chem. React. Eng. 2009, 7. [CrossRef]

45. Kruggel-Emden, H.; Rickelt, S.; Stepanek, F.; Munjiza, A. Development and testing of an interconnected multiphase CFD-model for chemical looping combustion. Chem. Eng. Sci. 2010, 65, 4732-4745. [CrossRef]

46. Mahalatkar, K.; Kuhlman, J.; Huckaby, E.D.; O’brien, T. Simulations of a circulating fluidized bed chemical looping combustion system utilizing gaseous fuel. Oil Gas Sci. Technol. 2011, 66, 301-311. [CrossRef]

47. Kruggel-Emden, H.; Stepanek, F.; Munjiza, A. A study on the role of reaction modeling in multi-phase CFD-based simulations of chemical looping combustion. Oil Gas Sci. Technol. 2011, 66, 313-331. [CrossRef]

48. Harichandan, A.B.; Shamim, T. CFD analysis of bubble hydrodynamics in a fuel reactor for a hydrogen-fueled chemical looping combustion system. Energy Convers. Manag. 2014, 86, 1010-1022. [CrossRef]

49. Wang, S.; Lu, H.; Zhao, F.; Liu, G. CFD studies of dual circulating fluidized bed reactors for chemical looping combustion processes. Chem. Eng. J. 2014, 236, 121-130. [CrossRef]

50. Wang, S.; Chen, J.; Lu, H.; Liu, G.; Sun, L. Multi-scale simulation of chemical looping combustion in dual circulating fluidized bed. Appl. Energy 2015, 155, 719-727. [CrossRef]

51. Banerjee, S.; Agarwal, R. Transient reacting flow simulation of spouted fluidized bed for coal-direct chemical looping combustion with different Fe-based oxygen carriers. Appl. Energy 2015, 160, 552-560. [CrossRef]

52. Zhang, Y.; Chao, Z.; Jakobsen, H.A. Modelling and simulation of chemical looping combustion process in a double loop circulating fluidized bed reactor. Chem. Eng. J. 2017, 320, 271-282. [CrossRef] 
53. Zhang, Z.; Zhou, L.; Agarwal, R. Transient simulations of spouted fluidized bed for coal-direct chemical looping combustion. Energy Fuels 2014, 28, 1548-1560. [CrossRef]

54. Guan, Y.; Chang, J.; Zhang, K.; Wang, B.; Sun, Q. Three-dimensional CFD simulation of hydrodynamics in an interconnected fluidized bed for chemical looping combustion. Powder Technol. 2014, 268, 316-328. [CrossRef]

55. Peng, Z.; Doroodchi, E.; Alghamdi, Y.A.; Shah, K.; Luo, C.; Moghtaderi, B. CFD-DEM simulation of solid circulation rate in the cold flow model of chemical looping systems. Chem. Eng. Res. Des. 2015, 95, 262-280. [CrossRef]

56. Geng, C.; Zhong, W.; Shao, Y.; Chen, D.; Jin, B. Computational study of solid circulation in chemical-looping combustion reactor model. Powder Technol. 2015, 276, 144-155. [CrossRef]

57. Mahalatkar, K.; Kuhlman, J.; Huckaby, E.D.; O’Brien, T. CFD simulation of a chemical-looping fuel reactor utilizing solid fuel. Chem. Eng. Sci. 2011, 66, 3617-3627. [CrossRef]

58. Su, M.; Zhao, H.; Ma, J. Computational fluid dynamics simulation for chemical looping combustion of coal in a dual circulation fluidized bed. Energy Convers. Manag. 2015, 105, 1-12. [CrossRef]

59. Sharma, R.; May, J.; Alobaid, F.; Ohlemueller, P.; Stroehle, J.; Epple, B. Euler-Euler CFD simulation of the fuel reactor of a $1 \mathrm{MWth}$ chemical-looping pilot plant: Influence of the drag models and specularity coefficient. Fuel 2017, 200, 435-446. [CrossRef]

60. May, J.; Alobaid, F.; Ohlemüller, P.; Stroh, A.; Ströhle, J.; Epple, B. Reactive two-fluid model for chemical-looping combustion-Simulation of fuel and air reactors. Int. J. Greenh. Gas Control 2018, 76, 175-192. [CrossRef]

61. Wang, X.; Jin, B.; Zhong, W.; Zhang, Y.; Song, M. Three-dimensional simulation of a coal gas fueled chemical looping combustion process. Int. J. Greenh. Gas Control 2011, 5, 1498-1506. [CrossRef]

62. Wang, X.; Jin, B.; Zhang, Y.; Zhong, W.; Yin, S. Multiphase computational fluid dynamics (CFD) modeling of chemical looping combustion using a $\mathrm{CuO} / \mathrm{Al}_{2} \mathrm{O}_{3}$ oxygen carrier: effect of operating conditions on coal gas combustion. Energy Fuels 2011, 25, 3815-3824. [CrossRef]

63. Wang, X.; Jin, B.; Zhang, Y.; Zhang, Y.; Liu, X. Three dimensional modeling of a coal-fired chemical looping combustion process in the circulating fluidized bed fuel reactor. Energy Fuels 2013, 27, 2173-2184. [CrossRef]

64. Wang, X.; Jin, B.; Liu, H.; Zhang, B.; Zhang, Y. Prediction of In-Situ Gasification Chemical Looping Combustion Effects of Operating Conditions. Catalysts 2018, 8, 526. [CrossRef]

65. Wang, X.; Shao, Y.; Jin, B.; Zhang, Y. Three-dimensional multiphase full-loop simulation of directional separation of binary particle mixtures in high-flux coal-direct chemical-looping combustion system. Particuology 2019. [CrossRef]

66. Gordillo, E.D.; Belghit, A. A two phase model of high temperature steam-only gasification of biomass char in bubbling fluidized bed reactors using nuclear heat. Int. J. Hydrogen Energy 2011, 36, 374-381. [CrossRef]

67. Jin, B.; Wang, X.; Zhong, W.; Tao, H.; Ren, B.; Xiao, R. Modeling on high-flux circulating fluidized bed with Geldart group B particles by kinetic theory of granular flow. Energy Fuels 2010, 24, 3159-3172. [CrossRef]

68. Benyahia, S.; Syamlal, M.; O'Brien, T.J. Study of the ability of multiphase continuum models to predict core-annulus flow. AIChE J. 2007, 53, 2549-2568. [CrossRef]

69. Ding, J.; Gidaspow, D. A bubbling fluidization model using kinetic theory of granular flow. AIChE J. 1990, 36, 523-538. [CrossRef]

70. Gidaspow, D.; Bezburuah, R.; Ding, J. Hydrodynamics of circulating fluidized beds: Kinetic theory approach. In Proceedings of the 7th Engineering Foundation Conference on Fluidization, Brisbane, Australia, 3-8 May 1992.

71. Umeki, K.; Yamamoto, K.; Namioka, T.; Yoshikawa, K. High temperature steam-only gasification of woody biomass. Appl. Energy 2010, 87, 791-798. [CrossRef]

72. Abad, A.; Adánez, J.; García-Labiano, F.; de Diego, L.F.; Gayán, P. Modeling of the chemical-looping combustion of methane using a Cu-based oxygen-carrier. Combust. Flame 2010, 157, 602-615. [CrossRef]

73. Lim, C.N.; Gilbertson, M.A.; Harrison, A.J.L. Bubble distribution and behaviour in bubbling fluidised beds. Chem. Eng. Sci. 2007, 62, 56-69. [CrossRef]

74. Scott, S.A.; Dennis, J.S.; Hayhurst, A.N.; Brown, T. In situ gasification of a solid fuel and $\mathrm{CO}_{2}$ separation using chemical looping. AIChE J. 2006, 52, 3325-3328. [CrossRef]

75. Cheng, L.; Basu, P. Effect of pressure on loop seal operation for a pressurized circulating fluidized bed. Powder Technol. 1999, 103, 203-211. [CrossRef] 
76. Kim, S.W.; Kim, S.D. Effects of particle properties on solids recycle in loop-seal of a circulating fluidized bed. Powder Technol. 2002, 124, 76-84. [CrossRef]

77. Wang, X.; Jin, B.; Liu, X.; Zhang, Y.; Liu, H. Experimental investigation on flow behaviors in a novel in situ gasification chemical looping combustion apparatus. Ind. Eng. Chem. Res. 2013, 52, 14208-14218. [CrossRef]

78. Wang, X.; Jin, B.; Liu, H.; Wang, W.; Liu, X.; Zhang, Y. Optimization of in situ gasification chemical looping combustion through experimental investigations with a cold experimental system. Ind. Eng. Chem. Res. 2015, 54, 5749-5758. [CrossRef]

79. Chen, X.Z.; Shi, D.P.; Gao, X.; Luo, Z.H. A fundamental CFD study of the gas-solid flow field in fluidized bed polymerization reactors. Powder Technol. 2011, 205, 276-288. [CrossRef]

(C) 2019 by the authors. Licensee MDPI, Basel, Switzerland. This article is an open access article distributed under the terms and conditions of the Creative Commons Attribution (CC BY) license (http://creativecommons.org/licenses/by/4.0/). 